Canada's Native

Languages:

The Right of First

Nations to Educate

Their Children

in Their Own

Languages

\title{
David Leitch
}

\section{Introduction}

Canada used to consider itself not only a bilingual, but also a bicultural country. ${ }^{1}$ Biculturalism was based on the idea that Canada had two founding cultures, the French-language culture dominant in Quebec and the English-language culture dominant everywhere else, with French and English minorities scattered across the country. This view of Canada obviously failed to recognize both the Aboriginal cultures that existed prior to European contact and the cultures of those immigrants who came to Canada with no knowledge of French or English or with knowledge of those languages but otherwise distinguishable cultures.

Prime Minister Pierre Trudeau appeared to announce the death of biculturalism in 1971 when his government introduced the policy of multiculturalism. He declared at that time that Canada no longer had any "official" cultures. ${ }^{2}$ But this only replaced the old fiction with a new one. In the same term of office in which Mr. Trudeau denied the existence of official cultures, he passed a law recognizing French and English as Canada's official languages. ${ }^{3}$
Now, there is no more distinguishing feature of most cultures than their languages. Nor is there a more meaningful way for a country to recognize and preserve any of its constituent cultures than to constitutionalize the right to educate children in the language of that culture at public expense. That is precisely the right that Mr. Trudeau delivered to the English and French minorities of Canada through section 23 of the Canadian Charter of Rights and Freedoms. ${ }^{4}$ Moreover, as will been seen, the Supreme Court of Canada has unequivocally affirmed that the main purpose of this right is to preserve and promote the cultures associated with those languages.

In other words, Canada's brand of multiculturalism does not place all cultures on an equal footing. The Charter may protect all cultures and languages from governmental interference, ${ }^{5}$ but it only explicitly gives the right to publicly funded education to Canada's official language minorities, that is, the anglophone minority inside Quebec and the francophone minorities located in other provinces and territories.

Despite what is provided for in the Charter, this paper nevertheless asks whether Canada's First Nations also have the constitutional right to educate their children in their own languages 
at public expense. It attempts to answer this question by examining the following subissues:

1. How has education in Aboriginal languages been governed since Confederation?

2. Even if it is not their constitutional right, can and should Canada's First Nations have the legislated right to educate their children in their own languages at public expense?

3. Does section 35 of the Constitution Act, 1982 constitutionalize this right?

4. If so, what is the value of this constitutional right to First Nations?

The paper refers briefly to the international law implications of the question posed, but proposes an answer based entirely on Canadian constitutional law. That choice is deliberate: while the reader might disagree with the paper's interpretation of domestic law, there can be no dispute that, properly interpreted, that law applies in Canada and binds Canadian governments. ${ }^{6}$

\section{How Has Education in Aboriginal Languages Been Governed Since Confederation?}

Pre-confederation treaties between $\mathrm{Ab}$ original and non-Aboriginal peoples were for peace and friendship. Upon Confederation in 1867, the federal government acquired exclusive jurisdiction over "Indians, and Lands reserved for the Indians." Between 1871 and 1923, the federal government entered into an additional thirteen treaties with First Nations, eleven numbered treaties and the two "Williams" treaties. The text of these historical treaties ${ }^{8}$ dealt primarily with the creation of Indian reserves and the maintenance of Aboriginal hunting and fishing rights. Education for Aboriginal children was mentioned only in the numbered treaties, and then only in the vaguest of terms and never with any reference to the language of instruction. Treaty No. 7 was typical:
Further, Her Majesty agrees to pay the salary of such teachers to instruct the children of said Indians as to Her Government of Canada may seem advisable, when said Indians are settled on their Reserves and shall desire teachers. ${ }^{9}$

The vagueness of the historical treaties is explained by a comment found in the body of Treaty No. 10, signed in 1906:

As to education, the Indians were assured that there was no need for special stipulation over and above the general provision in the treaty, as it was the policy of the government to provide in every part of the country as far as circumstances would permit, for the education of the Indian children, and that the law provided for schools for Indians maintained and assisted by the government. ${ }^{10}$

Despite the vagueness of the historical treaties, the federal government had very definite ideas about the kinds of schools it intended to provide. Under predecessors to the current Indian Act, ${ }^{11}$ the government embarked upon a century-long attempt to assimilate native children by placing up to one third of them (approximately 100,000) in residential schools under the direct control of Anglican, Catholic, Presbyterian, and Methodist churches. Over 100 such schools were established in all but two provinces. Contrary to the treaties, these schools were not always located on reserves. Even if they were, Aboriginal children were isolated from their families and communities, were forbidden to speak their native languages, and were severely punished for doing so. The Annual Report of the Department of Indian Affairs in 1895 outlined the goal of residential schools: "If it were possible to gather in all the Indian Children and retain them for a certain period, there would be produced a generation of English-speaking Indians, accustomed to the ways of civilized life."12

Since the closing of the last residential schools in the early 1980s, the federal government has not passed any legislation recognizing the right of First Nations to educate their children in their own languages. It has, instead, allowed Indian school boards greater control over the 500 or more onreserve schools. This increased autonomy has 
been achieved through a combination of block funding arrangements ${ }^{13}$ and bilateral transfer agreements between individual bands and the Department of Indian Affairs and Northern Development. Canadian Heritage, another branch of the federal government, also funds Aboriginal language initiatives undertaken by both local and national Indian organizations. These bureaucratically controlled measures have permitted some First Nations to educate their children in their own languages. They have not, however, given First Nations an enforceable right to educate their children in their own languages, and they have not imposed on the federal government an enforceable obligation to fund such education.

Since education is a matter of provincial or territorial jurisdiction in Canada, ${ }^{14}$ it may be thought that any federal legislation establishing those kinds of rights and obligations would be unconstitutional. It would not. Aboriginal languages are incontrovertibly located at the core of "Indianness." Education of Aboriginal children in those languages has, therefore, always remained within the primary, if not the exclusive, authority of the federal government. Yet, the federal government has never asserted its full legislative authority in this area. On the contrary, the federal government has equipped itself with the power to effectively delegate this authority to the provinces and territories. Under section 88 of the federal Indian Act, the federal government can simply adopt, without any federal legislation, "all laws of general application in force from time to time in any province" and make those laws "applicable to and in respect of Indians in the province." According to the Supreme Court of Canada, this section authorizes the federal government to "incorporate by reference" provincial laws of general application even when the application of those laws to Indians alters or impairs their "Indianness." ${ }^{15}$ Section 114 of the current Indian Act still permits the federal government to enter into agreements with provinces and territories for the education of Indian children.

It is true that section 88 does not permit provincial laws to override treaty rights but, as noted, the text of the historical treaties was silent on the language of education. Of course, since the Supreme Court of Canada's decision in Marshall $1,{ }^{16}$ the interpretation of treaties is no longer restricted to the written text. Extrinsic evidence of the historical and cultural context, as well as oral representations and understandings, may be also considered even in the absence of any ambiguity on the fact of the treaty. It would, therefore, be open to a First Nation to present oral evidence establishing that on its understanding of the agreement reached, the treaty included its right to educate its children in its own language.

However, it must be acknowledged that such evidence might not be available, might prove to be ambiguous, or might even suggest the opposite conclusion. In the Thomas case, the trial judge observed:

In the present case, evidence was given by the Chief of the Peguis Band, that according to oral tradition, the purpose of the education clause in Treaty No. 1 was to provide educational services to the Indians to enable them to compete with non-Indians in the post-Treaty era. ${ }^{17}$

This type of evidence would, arguably, support a finding that the First Nation understood and accepted that its children would learn things that would "enable them to compete with non-Indians," including, presumably, non-Indian languages. Indeed, the historical context might also support a finding that, at the time the treaty was entered into, the First Nation was still unaware of both the potential threat to the survival of its own language and the potential need, generations later, to ensure the survival of the language by teaching it to children in schools established under the treaty. In any event, even if a court accepted that oral or other evidence supported a finding that an historical treaty included the First Nation's right to educate its children in its own language, that finding would be based on the evidence in that case and would not necessarily assist other First Nations. It would clearly not assist First Nations who never entered into treaties with Canada or the United Kingdom. 
It is also true that recent education and self-government agreements in three provinces have recognized the right of First Nations to determine the language of education of their children. Here again, however, the implementation of that right is achieved through a combination of federal and provincial laws, which are limited to the Indian bands and the provinces in question. Not unexpectedly, the result is a patchwork of laws across the country that may be summarized as follows.

In seven of the ten provinces, English and French are the only languages of instruction in public schools. This is the case in Alberta, Manitoba, New Brunswick, Newfoundland and Labrador, Ontario, Saskatchewan, and Prince Edward Island. In these provinces, Aboriginal languages may be the subject of study in publicly funded schools attended by Aboriginal children, but First Nations have no right to educate their children in their own languages.

In three of the ten provinces - Nova Scotia, British Columbia, and Quebec - agreements on education or self-government give certain First Nations the right to determine the language of education of their children in publicly funded schools. In Nova Scotia, this is accomplished through a federal statute and a provincial statute, both called the Mi'kmaq Education Act. ${ }^{18}$ In British Columbia, it is accomplished through a federal statute and a provincial statute, both called the Nisga'a Final Agreement Act, ${ }^{19}$ and through the federal Sechelt Indian Band SelfGovernment $A c t^{20}$ and the provincial Sechelt Indian District Enabling Act. ${ }^{21}$ In Quebec, it is accomplished through the federal Cree-Naskapi (of Quebec) Act, ${ }^{22}$ the provincial Act Respecting Cree, Inuit and Naskapi Native Persons, ${ }^{23}$ and the provincial Charter of the French Language. ${ }^{24}$ First Nations in these three provinces who are not covered by these laws have no right to educate their children in their own language in publicly funded schools. ${ }^{25}$

There are three territories in Canada: the Northwest Territories, Nunavut, and the Yukon. Under the education statutes of both the Northwest Territories and Nunavut, ${ }^{26}$ the language(s) of instruction are determined by District Education Authorities, who may choose any one or more of the languages recognized under official languages statutes. There are ten official languages in the Northwest Territories: Cree, English, French, Gwich'in, Inuinnaqtun, Inuktitut, Inuvialuktun, North Slavey, South Slavey, and Taîchô. There are eight official languages of Nunavut: Chipewyan, Cree, Dogrib, English, French, Gwich'in, Inuktitut, and Slavey. In the Yukon, the Minister of Education may authorize an educational program or part of an educational program to be provided in an Aboriginal language after receiving a request to do so from a School Board, Council, school committee, Local Indian Education Authority or, if there is no Local Indian Education Authority, from one of the Yukon First Nations recognized under the federal Yukon First Nations Self-Government Act. $^{27}$

\section{Even If It Is Not Their Constitutional Right, Can and Should Canada's First Nations Have the Legislated Right to Educate Their Children in Their Own Languages at Public Expense?}

First Nations are not properly regarded as "minorities" in Canada. They are instead peoples whose ancestors inhabited North America long before European contact. Indeed, this fact was accepted as the foundation of Aboriginal rights by the Chief Justice of the Supreme Court of Canada in 1996 the leading case of R. v. Van der Peet:

In my view, the doctrine of aboriginal rights exists, and is recognized and affirmed by s. 35(1), because of one simple fact: when Europeans arrived in North America, aboriginal peoples were already here, living in communities on the land, and participating in distinctive cultures, as they had done for centuries. It is this fact, and this fact above all others, which separates aboriginal peoples from all other minority groups in Canadian society and which mandates their special legal, and now constitutional, status. ${ }^{28}$ 
This paper will presently turn to the question of whether section 35(1) of the Constitution Act, $1982^{29}$ constitutionalizes the right of First Nations to educate their children in their own languages at public expense. However, it must first be emphasized that even if, contrary to the views expressed later in the paper, this right has not been constitutionalized, it still can and should be recognized through ordinary federal and provincial legislation.

In theory, this kind of legislation would be open to attack by minority languages groups on the ground that it violates their right to equality under the Charter..$^{30}$ In practice, section 25 of the Charter pre-empts such attacks by stipulating that the Charter cannot be used to "abrogate or derogate from any aboriginal, treaty or other rights . . . that pertain to the aboriginal peoples of Canada." 31 This means that even if the right of First Nations to educate their children in their own languages is not a constitutional right, it is still possible for that right to be created and implemented by ordinary federal and provincial legislation and, hence, included in the expression "other rights ... that pertain to the aboriginal peoples of Canada." ${ }^{32}$ As such, the legislated right would be sheltered from attack by other minority language groups seeking the same right.

As for the reasons why Canada's First Nations should have the legislated right to educate their children in their own languages at public expense, there are at least three. First, of Canada's fifty-three native languages, all but three - Cree, Inuktitut, and Obijway - are extinct or will soon cease to exist unless they are taught to the children and grandchildren of the dwindling numbers of people who still speak them. These languages may also be spoken in the United States, but are under equal, if not greater, threat of extinction. The near-death status of most Aboriginal languages makes their situation dramatically different from that of other languages in Canada, all of which are spoken elsewhere in the world.

Second, the precarious state of most Aboriginal languages is a direct result of residential schools. No other cultural group in Canada has been subject to a state-sponsored attempt to eradicate its language. English-speaking provincial governments have often refused to fund
French-language schools and, in one province, prohibited instruction in French for a period of time. ${ }^{33}$ Immigrant children have always been required to learn, if they did not already know it, the language of instruction of Canada's public schools. But residential schools were again dramatically different. They did more than teach Aboriginal children English or French; they isolated those children from their families and communities for the express purpose of destroying their knowledge of their own languages and cultures. In these circumstances, it is not enough that residential schools were eventually closed or that some residential school victims may eventually recover damage awards for their language losses. ${ }^{34}$ First Nation communities should now be given the legislated right to educate their children in their own language at public expense.

There is a third reason to accord First Nations this right. By doing so, Canada would conform to the emerging international standards set by other countries with indigenous populations, such as the United States, Finland, and New Zealand. ${ }^{35}$

\section{Does Section 35 of the Constitution Act, 1982 Constitutionalize the Right of First Nations to Educate Their Children in Their Own}

\section{Languages?}

Our topic requires us to examine the import of the first three subsections of section 35 of the Constitution Act, 1982, ${ }^{36}$ as set out below. The fourth and last subsection of section 35 reads as follows: "Notwithstanding any provision of this Act, the aboriginal and treaty rights referred to in subsection (1) are guaranteed equally to male and female persons." ${ }^{37}$ While this provision is obviously important, it is not, in the present context, capable of generating serious legal debate. 


\section{(A) Section 35(1): “The existing aboriginal and treaty rights of the aboriginal peoples of Canada are hereby recognized and affirmed."}

According to the Supreme Court of Canada's 1990 decision in R. v. Sparrow, this subsection constitutionalizes "existing aboriginal and treaty rights." 38 Given the potential difficulties and limitations of arguments based on treaty rights, as noted above, this paper focuses on whether First Nations still possess "existing aboriginal rights" to educate their children in their own languages. This question raises two issues: (1) Did First Nations ever have that "Aboriginal right"?; and (2) Did they still have it in 1982, when section 35(1) was adopted?

(i) Did First Nations ever have the "Aboriginal right" to educate their children in their own languages?

The leading case on the definition of "Aboriginal rights" is again the Supreme Court of Canada's 1996 decision in R. v. Van der Peet. ${ }^{39}$ The Court there noted that Aboriginal rights were recognized by the common law prior to 1982. The Court stated that their further recognition under section 35(1) was "directed towards the reconciliation of the pre-existence of aboriginal societies with the sovereignty of the Crown." ${ }^{\prime \prime 0}$ For constitutional purposes, the Court adopted the following definition of Aboriginal rights: "the practices, traditions and customs central to the Aboriginal societies that existed in North America prior to contact with the Europeans." ${ }^{11}$

Beyond this basic definition, the Court held that in order to be "central" to the Aboriginal society in question, the activity had to be "integral" to its "distinctive culture":

The court cannot look at those aspects of the aboriginal society that are true of every human society (e.g., eating to survive), nor can it look at those aspects of the aboriginal society that are only incidental or occasional to that society; the court must look instead to the defining and central attributes of the aboriginal society in question. ${ }^{42}$
The Court also required that the pre-contact practice, custom, and tradition "have continuity with" the present-day practice, custom, and tradition claimed as an Aboriginal right. ${ }^{43}$

Since every human society has created its own language, it might be argued that an Aboriginal society's need to communicate was equivalent to its need to "eat to survive," and that its language could not, therefore, be described as distinctive to its culture. However, in Van der Peet, the Court was careful to emphasize that Aboriginal rights are defined by their "distinctiveness," not their "distinctness." It gave the following example drawn from its previous decision in Sparrow:

Certainly no aboriginal group in Canada
could claim that its culture is "distinct" or
unique in fishing for food; fishing for food is
something done by many different cultures
and societies around the world. What the
Musqueam claimed in Sparrow... was rather
that it was fishing for food which, in part, made
Musqueam culture what it is; fishing for food
was characteristic of Musqueam culture and,
therefore, a distinctive part of that culture.
Since it was so it constituted an aboriginal
right under s. $35(1) .{ }^{44}$

It might also be argued that the education of children in schools was foreign to Aboriginal societies prior to contact with Europeans. This may well be true, particularly in relation to reading, writing, and other academic subjects. It is nonetheless certain that Aboriginal societies educated their children in their own languages in their own ways, successfully transmitting those languages from generation to generation prior to European contact. According to the Van der Peet decision, Aboriginal rights are not to be denied just because Aboriginal societies "adapted" their practices, customs, and traditions in response to the arrival of Europeans. It is only "where the practice, custom or tradition arose solely as a response to European influences" that it fails to meet the standard for recognition as an Aboriginal right. ${ }^{45}$ Looked at from this perspective, Aboriginal societies are entitled to adapt their teaching methods without losing their Aboriginal right to continue teaching their children in their own languages. As the Court observed: 
The evolution of practices, customs and traditions into modern forms will not, provided that continuity with pre-contact practices, customs and traditions is demonstrated, prevent their protection as aboriginal rights. ${ }^{46}$

Moreover, when considering the effect of residential schools, it is important to note the Court's willingness to overlook certain breaks in "continuity" between pre-contact and present-day practices, customs, and traditions. The Court rejected the need for proof of "an unbroken chain of continuity," stating:

\begin{abstract}
It may be that for a period of time an aboriginal group, for some reason, ceased to engage in a practice, custom or tradition which existed prior to contact, but then resumed the practice, custom or tradition at a later date. Such an interruption will not preclude the establishment of an aboriginal right. ${ }^{47}$
\end{abstract}

Finally, the Van der Peet decision makes it impossible to argue that Aboriginal rights can only be asserted in relation to physical resources such as land, game, or fish, and not in relation to intellectual resources such as languages. The Court wrote:

Aboriginal rights arise from the prior occupation of land, but they also arise from the prior social organization and distinctive cultures of aboriginal peoples on that land. In considering whether a claim to an aboriginal right has been made out, courts must look at both the relationship of an aboriginal claimant to the land and at the practices, customs and traditions arising from the claimant's distinctive culture and society. Courts must not focus so entirely on the relationship of aboriginal peoples with the land that they lose sight of the other factors relevant to the identification and definition of aboriginal rights. ${ }^{48}$

It must be acknowledged that the Supreme Court of Canada has yet to comment on the status of Aboriginal languages under section 35(1). It has, however, decided numerous cases involving section 23 of the Charter. As will be recalled, this is the section of the Charter that gives official language minorities the constitutional right to educate their children in their own language at public expense. The Court's decisions in this area have always emphasized the link between the right to educate children in a particular language and the maintenance of the distinctive culture associated with that language. The most eloquent description of that link is found in the 1990 decision of Mahe $v$. Alberta,${ }^{49}$ in which Dickson Chief Justice wrote and quoted as follows:

The general purpose of s. 23 is clear: it is to preserve and promote the two officiallanguages of Canada, and their respective cultures, by ensuring that each language flourishes, as far as possible, in provinces where it is not spoken by the majority of the population. The section aims at achieving this goal by granting minority language educational rights to minority language parents throughout Canada.

My reference to cultures is significant: it is based on the fact that any broad guarantee of language rights, especially in the context of education, cannot be separated from a concern for the culture associated with the language. Language is more than a mere means of communication, it is part and parcel of the identity and culture of the people speaking it. It is the means by which individuals understand themselves and the world around them. The cultural importance of language was recognized by this Court in Ford v. Quebec (Attorney General):

\begin{abstract}
Language is not merely a means or medium of expression; it colours the content and meaning of expression. It is, as the preamble of the Charter of the French Language itself indicates, a means by which a people may express its cultural identity. ${ }^{50}$
\end{abstract}

There is no reason to believe that the Supreme Court of Canada would regard education in Aboriginal languages as less important for the distinctive cultures of First Nations than education in English and French for the distinctive cultures of Canada's official language minorities.

(ii) Did First Nations still have the "Aboriginal right" to educate their children in their own language in 1982, when section 35(1) was adopted? 
Section 35(1) constitutionalizes only "existing aboriginal . . . rights." Since there were no relevant constitutional amendments prior to 1982, the Aboriginal rights of First Nations continued to exist thereafter unless they were extinguished prior to 1982 either by treaty or by federal legislation.

Dealing first with extinguishment by treaty, it is settled law that any ambiguities or doubtful expressions in the wording of treaties must be resolved in favour of the Indians. In its 1996 decision in R. v. Badger, the Court reiterated that "any limitations which restrict the rights of Indians under treaties must be narrowly construed." 51 The historical treaties contemplated the establishment of schools, but they placed no restrictions on the language of instruction and did not, therefore, extinguish the right of First Nations to educate their children in their own languages.

As for pre-1982 federal laws, the Sparrow decision held that such laws could extinguish Aboriginal rights only if they manifested a "clear and plain intention" to do so. ${ }^{52}$ Just as there has never been a federal law recognizing the right of First Nations across Canada to educate their children in their own languages, neither has there ever been a federal law expressly extinguishing this right. The policies of residential schools were obviously inconsistent with the exercise of that right, but these were policies, not laws, and they did not affect all First Nations in the same way. Indeed, in Sparrow, the Court held that even valid federal laws restricting or regulating Aboriginal rights did not extinguish those rights. The Court observed that incorporating such laws into a section 35 analysis would freeze a "constitutional patchwork quilt" reflecting nothing more than the different ways the Aboriginal rights of different First Nations happened to be regulated in 1982 or before. The Court again declared: “The phrase 'existing aboriginal rights' must be interpreted flexibly so as to permit their evolution over time." 53

Finally, in view of the importance of provincial laws as explained above, it must be emphasized that such laws are incapable of extinguishing Aboriginal rights. In the 1997 case of Delgamuukw v. British Columbia, the Supreme Court held that even when provincial laws are "adopted" by the federal government under section 88 of the Indian $A c t,{ }^{54}$ that section "does not evince the requisite clear and plain intent to extinguish aboriginal rights." 55

\section{(B) Section 35(2): “' $[A]$ boriginal peoples of Canada' includes the Indian, Inuit and Métis peoples of Canada”}

This subsection is of particular significance for the Métis, people of mixed Aboriginal and European ancestry. The Van der Peet decision anticipated that the Aboriginal rights of this group would have to be defined differently than those of the Indian and Inuit peoples. In its 2003 decision in R. v. Powley, ${ }^{56}$ the Supreme Court confirmed that because the Métis people developed their own identity and ways of life after the European arrival, their Aboriginal rights could not be fairly defined using the preEuropean contact test adopted in Van der Peet. Instead, the Court enunciated the following test for the definition of Métis Aboriginal rights:

[Their] unique history can most appropriately be accommodated by a post-contact but precontrol test that identifies the time when Europeans effectively established political and legal control in a particular area. The focus should be on the period after a particular Métis community arose and before it came under the effective control of European laws and customs. This pre-control test enables us to identify those practices, customs and traditions that predate the imposition of European laws and customs on the Métis. ${ }^{57}$

The Métis language, Mitchif, a blend of French, Cree, Ojibway, and Dene is, therefore, an Aboriginal language for the purposes of the present inquiry.

(C) Section 35(3): “For greater certainty, in subsection (1) 'treaty rights' includes rights that now exist by way of land claims agreements or may be so acquired"

This subsection, added in 1983, anticipates the signing of "modern" treaties or "land claims agreements," and appears to recognize 
their constitutional status. As noted above, the federal government has, in fact, signed various transfer, educational, and self-government agreements with First Nations since 1982 and has also passed enabling legislation in three provinces and one territory. However, the federal government has not been prepared to acknowledge the constitutional status of these arrangements without the participation and agreement of the province concerned, as was obtained in the Nisga'a Final Agreement. ${ }^{58}$ The Federal Policy Guide on Aboriginal SelfGovernment states:

As a general principle, existing self-government agreements will continue to operate according to their existing terms. If requested by the Aboriginal groups concerned, and with the full participation of the province or territory concerned, the federal government would be prepared to explore issues related to constitutional protection of aspects of the self-government arrangements set out in the Sechelt Indian Band Self-Government Act in British Columbia, the Cree-Naskapi (of Quebec) Act, and the Yukon First Nations SelfGovernment Act. Any changes or amendments to existing arrangements, however, would only be made with the full agreement of all parties concerned. ${ }^{59}$

It should be noted that in the same document, the federal government acknowledged that Aboriginal self-government should extend "to matters that are internal to the group, integral to its distinct Aboriginal culture" 60 and, in that regard, specifically mentioned Aboriginal languages and education.

Ironically, since self-government negotiations deal with all sorts of other matters beside language rights and tend to be very protracted, they have effectively prevented First Nations from establishing their constitutional right to educate their children in their own language. That is because while these negotiations have produced very few constitutionally recognized treaties including that right, they have discouraged First Nations from asserting that right in the courts. Let us nevertheless assume that the Supreme Court of Canada has just decided that section 35 does recognize and affirm the Aboriginal and, therefore, the constitutional right of First Nations to educate their children in their own languages. What value would that constitutional right have to First Nations?

\section{What is the Value of This Constitutional Right to First Nations?}

On one view of the matter, this Aboriginal/ constitutional right would have little value to First Nations. True, the federal government could no longer legislate that right out of existence, but First Nations already have protection against that remote possibility through the Charter's guarantee of freedom of expression. ${ }^{61}$ Moreover, according to the Supreme Court's decision in Sparrow, the federal government would still be entitled to regulate or otherwise infringe upon the right so long as it could meet a standard of justification involving proof of the following: that the regulation was for a "compelling and substantial" objective, that it respected "the special relationship of trust" between the Crown and Aboriginal peoples, that it infringed as little as possible on the right, and that it was implemented in consultation with First Nations. ${ }^{62}$ Provincial laws of general application would also be allowed to regulate or infringe upon the right under the authority of section 88 of the Indian Act, ${ }^{63}$ subject to the same standard of justification. Finally, the Aboriginal/constitutional right recognized by section 35 would not include an explicit guarantee of public funding for Aboriginal language education; that kind of guarantee has only been given to Canada's official language minorities through section 23 of the Charter.

These observations may be legally accurate, but they do not provide a proper measure of the potential value of the Aboriginal/constitutional right at issue. Such an appraisal requires an analysis of the right from two additional perspectives: (1) the nature of the right, and (2) its relationship with the Royal Proclamation of 1763. 


\section{(A) Nature of the Right}

Supreme Court jurisprudence to date has only analyzed Aboriginal/constitutional rights in the context of access to physical resources such as land, game, or fish. First Nations have asserted their rights in these cases in order to stop governments from authorizing activities that threatened to eliminate or reduce their access to those resources.

In constitutional law terms, this kind of right is often called a "negative" right. It operates to negate the authority of any government to extinguish or infringe upon Aboriginal/ constitutional rights, though, as just noted, infringements are still possible on proof of justification. Most of the provisions contained in the Charter operate in the same way. They negate the authority of any government to deprive citizens of certain rights and liberties, such as equality, freedom of expression, or freedom of association, unless those violations can be justified under section 1 of the Charter.

Now, in the present context, freedom of expression is not just another right guaranteed by the Charter. On the contrary, it guarantees, among other things, the right of all citizens to educate their children in their own, nonofficial, languages at their own expense. It would, therefore, make little sense to regard the Aboriginal/constitutional right of First Nations to educate their children in their own languages as merely a reaffirmation of the "negative" right they already possess under the Charter. It makes more sense to regard that right as a "positive" right intended not to negate governmental authority, but rather to impose governmental responsibility.

This view, in fact, is concordant with the Supreme Court of Canada's views about the nature of language rights generally. In its 1999 decision in R. v. Beaulac, a majority of the Court wrote:

Language rights are not negative rights or passive rights; they can only be enjoyed if the means are provided. This is consistent with the notion favoured in the area of international law that the freedom to choose is meaningless in the absence of a duty of the State to take positive steps to implement language guarantees. ${ }^{64}$

Addressing specifically the Charter right to educate children in the official languages of Canada, the Supreme Court's 1990 decision in Mahe stated:

The provision provides for a novel form of legal right, quite different from the type of legal rights which courts have traditionally dealt with. Both its genesis and its form are evidence of the unusual nature of s. 23. Section 23 confers upon a group a right which places positive obligations on government to alter or develop major institutional structures. ${ }^{65}$

Moreover, there is no doubt that the provincial and federal governments of Canada already have positive obligations to provide funds for the education of all children, whether Aboriginal or not, and whether covered by treaties or not. Are those governments relieved of any duty to respect the Aboriginal/ constitutional right of First Nations to educate their children in their own languages merely because that right, unlike the right given by section 23, is not accompanied by an explicit guarantee of public funding? Sections 16 to 20 of the Charter contain no explicit reference to public funding either, but there is nevertheless no doubt that the Governments of Canada and New Brunswick are constitutionally bound to provide the funding necessary to fulfill the positive language obligations imposed upon them by those provisions.

\section{(B) The Royal Proclamation of 1763}

As previously explained, the federal government could have asserted direct legislative authority over the education of Aboriginal children in Aboriginal languages across Canada, but has never done so. Again, on one view of the matter, government inaction of this kind was, and still is, constitutionally acceptable because no government is required to fully exercise its legislative authority. That authority is permissive, not mandatory. Where Aboriginal rights are concerned, however, there is a competing view, one that traces its origins back to the Royal Proclamation of 1763. 
The British had just defeated the French for control over most of North America, but had inherited a new and urgent problem. To colonize this vast territory, they needed first to come to terms with the still-powerful Aboriginal nations who did not consider themselves bound by the British victory, but who were prepared to recognize the British Crown if that would help to stem the steady encroachment of settlers onto their lands. The solution adopted by the Royal Proclamation of 1763 offered something for everyone: it asserted British sovereignty over all lands not already "ceded" by Aboriginal nations, i.e., most of the continent; it promised Aboriginal nations "who live under our Protection" undisturbed possession of these lands; and it created a process for further settlement, but only through future land surrenders to the Crown. This third feature forced local governments and settlers to acquire lawful title directly from the Crown, thus facilitating more peaceful colonial expansion. But it also created a monopoly over the terms on which Indians surrendered their lands, as they were specifically prohibited from transferring their lands to anyone but the Crown. On Confederation, control of this monopoly passed from the British Crown to the Government of Canada.

More than two hundred years after the Royal Proclamation, in the 1984 case of Guerin v. Canada, the Supreme Court of Canada held that the Crown-only surrender requirement "and the responsibility it entails" were "the source of a distinct fiduciary obligation owed by the Crown to the Indians." ${ }^{\prime 6}$ The Supreme Court then expanded the scope of the fiduciary duty in Sparrow by agreeing with a lower court that the federal government has the "'responsibility ... to protect the rights of Indians arising from the special trust relationship created by history, treaties and legislation."'67

It can, therefore, be asserted that the federal government has, and has always had, a fiduciary duty to protect the Aboriginal right of First Nations to educate their children in their own languages. That right was clearly part and parcel of their Royal Proclamation right to undisturbed possession of unceded land. Any suggestion that subsequent land cessions somehow diminished this right can be characterized as contrary to both logic and law: logic, because the continued exercise of this right does not require the reversal of any land cessions, and law, because only the continued exercise of this right permits its "evolution over time."

Moreover, if this right was constitutionalized in 1982, it can be further asserted that the federal government has, since then, had a double fiduciary duty to act to protect Aboriginal languages hovering on the brink of extinction. The submission would be that since the federal government can no longer pass a law extinguishing an Aboriginal language right recognized under section 35 of the Constitution Act, $1982,{ }^{68}$ it can also no longer fail or refuse to pass a law designed to protect that right from imminent extinction.

No doubt, the federal government would still maintain that it has acted, both by funding Aboriginal language initiatives and by allowing many First Nations greatercontrolover education generally. It might also dispute the need for federal legislation, alleging that such legislation could never accommodate the differing needs and attitudes of all First Nations.

However, where language education rights are concerned, a government can comply with its minimal constitutional obligation only by enacting laws turning that obligation into an enforceable right. This was made clear by the Supreme Court of Canada's decision in Mahe, regarding section 23 of the Charter. That section does not specifically require provincial legislatures to pass laws implementing the constitutional right. Yet, the Court described the constitutional obligation of those legislatures as follows:

[T] he government should have the widest possible discretion in selecting the institutional means by which its s. 23 obligations are to be met; the courts should be loathe to interfere and impose what will be necessarily procrustean standards, unless that discretion is not exercised at all, or is exercised in such a way as to deny a constitutional right. Once the Court has declared what is required in Edmonton, then the government can and must do whatever is necessary to ensure that 
these appellants, and other parents in their situation, receive what they are due under s. 23. Section 23 of the Charter imposes on provincial legislatures the positive obligation of enacting precise legislative schemes providing for minority language instruction and educational facilities where numbers warrant. To date, the legislature of Alberta has failed to discharge that obligation. It must delay no longer in putting into place the appropriate minority language education scheme. ${ }^{69}$

\section{Conclusion}

This paper has asked whether Canada's First Nations also have the constitutional right to educate their children in their own language at public expense. The word "also" acknowledges the fact that section 23 of the Charter $^{70}$ specifically gives that constitutional right to Canada's official language minorities. It is clear that First Nations do not have exactly the same right as official language minorities; the latter right is, for example, subject to the test of "where numbers warrant." The pedagogical challenges facing First Nations would also be very different than those facing official language minorities.

Still, this paper has proposed a positive answer to the question posed. It has done so by reading the Supreme Court of Canada's jurisprudence in relation to Aboriginal rights together with its jurisprudence in relation to section 23 of the Charter. The opinion expressed is that Parliament can be obliged to adopt legislation implementing the constitutional right of First Nations to educate their children in their own languages. Such legislation would give First Nations an enforceable right and would permit the courts to measure and evaluate that right against constitutional standards. The paper has also expressed the opinion that even if federal legislation implementing this right is not constitutionally required, it would still be within the joint legislative authority of the federal and provincial governments, it would be justified, and it would survive Charter scrutiny.

\section{Notes}

* David Garth Leitch, LL.B, LL.M, can be reached at davidgleitch@sympatico.ca. The author wishes to thank Judith Garber, Deborah Hawken, and Delia Opekakew for their comments on an earlier version of this paper. The opinions expressed can be attributed only to the author.

1 In 1963, the government of Prime Minister Lester B. Pearson appointed a public enquiry known as the Royal Commission on Bilingualism and Biculturalism. Its mandate was to recommend ways to recognize the equality of Canada's "two founding peoples."

2 House of Commons Debates (8 October 1971) at 8545 (Right Hon. P.E. Trudeau).

3 The federal government he led introduced the first Official Languages Act in 1969. See Official Languages Act, R.S.C. 1985, c. 35 (4 $4^{\text {th }}$ Supp.).

4 Part I of the Constitution Act, 1982, being Schedule B to the Canada Act 1982 (U.K.), 1982, c. 11 [Charter]. Section 23 provides:

(1) Citizens of Canada

a) whose first language learned and still understood is that of the English or French linguistic minority population of the province in which they reside, o

b) who have received their primary school instruction in Canada in English or French and reside in a province where the language in which they received that instruction is the language of the English or French linguistic minority population of the province, have the right to have their children receive primary and secondary school instruction in that language in that province.

(2) Citizens of Canada of whom any child has received or is receiving primary or secondary school instruction in English or French in Canada, have the right to have all their children receive primary and secondary school instruction in the same language.

(3) The right of citizens of Canada under subsections (1) and (2) to have their children receive primary and secondary school instruction in the language of the English or French linguistic minority population of a province

a) applies wherever in the province the number of children of citizens who have such a right is sufficient to warrant the provision to them out of public funds of minority language instruction; and 
b) includes, where the number of those children so warrants, the right to have them receive that instruction in minority language educational facilities provided out of public funds.

5 Ford v. Quebec (Attorney General), [1988] 2 S.C.R. 712, 1988 CanLII 19.

6 On 29 June 2006, Canada voted against adoption of the Draft Declaration on the Rights of

Indigenous Peoples at the inaugural session of the United Nations Human Rights Council. Article 14 of the Draft Declaration reads:

1. Indigenous peoples have the right to establish and control their educational systems and institutions providing education in their own languages, in a manner appropriate to their cultural methods of teaching and learning.

2. Indigenous individuals, particularly children, have the right to all levels and forms of education of the State without discrimination.

3. States shall, in conjunction with indigenous peoples, take effective measures, in order for indigenous individuals, particularly children, including those living outside their communities, to have access, when possible, to an education in their own culture and provided in their own language.

Report of the Human Rights Council, UN GA, 61st Sess., Annex, UN Doc. A/C.3/61/L.18/Rev.1 (2006), online UN High Commissioner for Human Rights <http://www.ohchr.org/english/ issues/indigenous/docs/wgdd2006/18-rev1.doc $>$.

7 Constitution Act, 1867 (U.K.), 30 \& 31 Vict., c. 3, s. 91(24), reprinted in R.S.C. 1985, App. II, No. 5.

8 These historical treaties can be found on the Department of Indian Affairs and Northern Development (DIAND) web site, online: <http:// www.ainc-inac.gc.ca/pr/trts/hti/site/trindex_ e.html>.

9 Canada, Copy of Treaty and Supplementary Treaty No. 7, Made 22 $2^{\text {nd }}$ Sept., and $4^{\text {th }}$ Dec., 1877, Between Her Majesty the Queen and the Blackfeet and Other Indian Tribes, at the Blackfoot Crossing of Bow River and Fort McLeod (Ottawa: Queen's Printer, 1966) [Treaty No. 7]. For an electronic version of Treaty No. 7, see online: DIAND $<$ http://www.ainc-inac.gc.ca/pr/trts/trty7_ e.html $>$.

10 Canada, Treaty No. 10 and Report of Commissioners (1907) (Ottawa: Queen's Printer, 1966) [Treaty No. 10]. For an electronic version of Treaty No. 10, see online: DIAND < http://www. ainc-inac.gc.ca/pr/trts/trty10_e.html>.

11 R.S.C. 1985 , c. I-5.

12 Canada, Dominion of Canada Annual Report of the Department of Indian Affairs (Ottawa:

Queen's Printer, 1895) at xxiii, online: Library and Archives Canada <http://www.collectionscanada. ca/indianaffairs/020010-119.01-e.php?uidc=ID\&u $\mathrm{id}=9777 \&$ sk $=$ \&query_string $=>$.

13 Thomas v. Canada (Minister of Indian Affairs and Northern Development), [1991] 2 F.C. 433 (T.D.) [Thomas].

14 See Constitution Act, 1867, supra note 7, s. 93; Yukon Act, S.C. 2002, c. 7, s. 18(o); Northwest Territories Act, R.S.C., 1985, c. N-27, s. 16(n); and Nunavat Act, S.C. 1993, c. 28, s. 23(m).

15 Dick v. The Queen, [1985] 2 S.C.R. 309, 1985 CanLII 80 at paras. $38,40-44$. This decision has been consistently followed and applied, most recently in R. v. Morris, 2006 SCC 59 (CanLII).

16 R. v. Marshall, [1999] 3 S.C.R. 456, 1999 CanLII 665 [Marshall 1].

17 Thomas, supra note 13 at 446.

18 S.C. 1998, c. 24; S.N.S. 1998, c. 17.

19 S.C. 2000 , c. 7; S.B.C. 1999 , c. 2.

20 S.C. 1986, c. 27.

21 R.S.B.C. 1996, c. 416.

22 S.C. 1984, c. 18.

23 R.S.Q., c. A-33.1.

24 R.S.Q., c. C-11.

25 A federal statute, First Nations Jurisdiction over Education in British Columbia Act, S.C. 2006, c. 10, received Royal Assent at the end of 2006 but is not in force at the time of publication. If this law comes into force, it will give participating First Nations in British Columbia the right to educate their children in their own languages in publicly funded schools.

26 S.N.W.T. 1995, c. 28.

27 S.C. 1994, c. 35.

28 [1996] 2 S.C.R. 507, 1996 CanLII 216, at para. 30, Lamer C.J.C. [emphasis in original] [Van der Peet].

29 Supra note 4.

30 Ibid.

31 Ibid., s. 25 [emphasis added].

32 Corbiere v. Canada (Minister of Indian and Northern Affairs) [1999] 2 S.C.R. 203, 1999 CanLII 687 at para. 52 [emphasis added] [Corbiere]. In Corbiere, four Supreme Court justices confirmed that "rights included in s. 25 are broader than those in s. 35 , and may include statutory rights."

33 Reference re Education Act of Ontario and Minority Language Education Rights (1984), 47 O.R. (2d) 1 (C.A.). 
34 Cloud v. Canada (Attorney General) (2004), 73 O.R. (3d) 401, 2004 CanLII 45444. The recent Indian Residential Schools Settlement Agreement of 8 May 2006 does not provide specific compensation for loss of language. It provides instead a "common experience payment" for all losses resulting from attendance at residential schools except sexual and serious physical abuse for which losses are assessed individually. See Official Court Notice, online: <http://www. residentialschoolsettlement.ca/Settlement.pdf $>$.

35 F. De Varennes, "Les droits linguistiques dans une perspective internationale" in Sylvie Léger, ed., Les droits linguistiques au Canada: Collusions ou collisions? (Ottawa: Centre canadien des droits linguistiques, 1995) c. 4.

36 Supra note 4.

37 Ibid., s. 35(4).

38 [1990] 1 S.C.R. 1075, 1990 CanLII 104 [Sparrow].

39 Supra note 28.

40 Ibid. at para. 31.

41 Ibid. at para. 44.

$42 \mathrm{Ibid}$. at para. 56.

43 Ibid. at paras. 60-67.

44 Ibid. at para. 72 [emphasis in original].

45 Ibid. at para. 73 .

46 Ibid. at para. 64

47 Ibid. at para. 65.

$48 \mathrm{Ibid}$. at para. 74 [emphasis in original].

49 [1990] 1 S.C.R. 342, 1990 CanLII 133 [Mahe].

50 Ibid. at 362 [emphasis in original].

51 [1996] 1 S.C.R. 771, 1996 CanLII 236 at para. 41.

52 Sparrow, supra note 38 at 1099.

53 Ibid. at 1093.

54 Supra note 11.

55 [1997] 3 S.C.R. 1010, 1997 CanLII 302 at para. 183 [Delgamuukw].

56 [2003] 2 S.C.R. 207, 2003 SCC 43 (CanLII).

57 Ibid. at para. 37.

58 (27 April 1999), online: DIAND <http://www. ainc-inac.gc.ca/pr/agr/nsga/nisdex12_e.pdf $>$.

59 Canada, Federal Policy Guide, "Aboriginal Self-Government: The Government of Canada's Approach to Implementation of the Inherent Right and the Negotiation of Aboriginal SelfGovernment" (1995), online: DIAND < http:// www.ainc-inac.gc.ca/pr/pub/sg/plcy_e.html>.

60 Ibid.

61 Supra note 4, s. 2(b).

62 Sparrow, supra note 38.

63 Supra note 11.

64 [1999] 1 S.C.R. 768, 1999 CanLII 684 at para. 20.

65 Supra note 49 at 365.

66 [1984] 2 S.C.R. 335 at 376, 1984 CanLII 25.

67 Supra note 38 at 1107, quoting R. v. Agawa
(1988), 28 O.A.C. 201 at para. 44 (C.A.), Blair J.A. 68 Supra note 4.

69 Supra note 49 at 393 [emphasis added]. 70 Supra note 4. 